\title{
THE UNITED STATES NATIONAL SPINAL CORD INJURY DATA RESEARCH CENTRE ${ }^{1}$
}

\author{
By John S. Young, M.D. \\ National Spinal Cord Injury Data Research Center, I033 East McDowell Road, \\ Phoenix, Arizona 85006
}

\section{Introduction}

The United States Department of Health, Education and Welfare funded the Southwest Regional System for Treatment of Spinal Injury in June 1970 to demonstrate a systemitised, holistic care programme for persons victimised by spinal cord injury. The system has been operative for five years and is in the process of preparing its final report. This project was preceded by a pilot programme at Rancho Los Amigos Hospital, Downey, California, 1966-1969, under the guidance of Stauffer, Nickel and Wilcox (Stauffer et al., 1969). Both projects borrowed liberally in their development from the regional experience of Craig Hospital in Englewood, Colorado, directed by Jackson and Young (Young, 1970), which espoused the concept of holistic spinal cord injury care pioneered by Munro (1948), Guttmann (1973) and Bors (1956). The model for categorical care for catastrophic disability was first established in the United States by the National Foundation for Infantile Paralysis in the form of its respiratory centers for the treatment of poliomyelitis (Affeldt, 1958; Landauer, 1958; Spencer, 1958).

Following the establishment of the Southwest Regional System for Treatment of Spinal Injury, the Department of Health, Education and Welfare funded nine other regional spinal cord injury research and demonstration systems, including:

University of Alabama Medical Center, Birmingham, Alabama

Santa Clara Valley Medical Center, San Jose, California

Craig Hospital, Englewood, Colorado

Northwest Memorial Hospital-Rehabilitation Institute of Chicago, Chicago, Illinois

University of Minnesota Medical Center, Minneapolis, Minnesota

New York University Medical Center, New York, New York

Texas Institute for Rehabilitation \& Research, Houston, Texas

Woodrow Wilson Rehabilitation Center-University of Virginia Medical Center, Fishersville and Charlottesville, Virginia

University of Washington Medical Center, Seattle, Washington.

The selection of these regional spinal cord injury centers with variation in their composition, organisation and methodology for providing services was a deliberate research design incorporated into the National Spinal Cord Injury Demonstration Project. When put together, data supplied by the individual

1 This project was supported in part by Social and Rehabilitation Service, Research and Demonstration Grant Number I3-P-55258/9. 
systems will give information not only on our spinal cord injury population, but also on the most productive methodology for supplying services to them. It will be a composite of those concepts demonstrated to be sound by the Regional Centres.

Each system has been charged with the individual responsibility of developing information on all aspects of spinal cord injury. They were particularly charged with developing information pertaining to the epidemiology and demography of spinal cord injury. Who gets hurt? How? When? Where? What sort of person was he before he was hurt and what sort of a person does he become after being hurt? What is the pattern and time sequence of services delivered to him? Does he receive proper services at the proper time? Is there continuity of care? What sort of follow-up care does he require to maintain an optimal life style? Even more basic-what is optimal ? How long do spinal cord people live? How well do they live? What can society expect from these disabled people? What should they expect and receive from society? Lastly, what is the cost of all these things? The cost of acute care, the cost of rehabilitation, the cost of maintenance? To what extent can this cost be offset by containment of personal costs and productive employment? How does the productivity of a system approach compare with an unsystemised approach? Is there an optimal system ? If not, are there identifiable essential components that can be linked together in a number of organisational arrangements to provide appropriate services at the appropriate time?

If we are to develop a valid composite profile of the pre-injured population and compare it with its post-injury counterpart, we must have a volume of patients far larger than that served by a single Regional Center. In order to get a clear prospective of the impact of spinal cord injury upon the injured person, who must live and cope with its sequelae, and upon society which must pay for his care, one must look at the consequences of spinal cord injury in the broadest aspectmedical, psychological, social and vocational. Each area of concern adds critical variables. Herein lies the problem confronting those concerned with evaluating results of care systems and treatment methodology designed to better the life of spinal cord injured persons. The problem is further compounded by the element of time. We do not rehabilitate quadriplegics or paraplegics in the sense that they achieve an optimal level and stay there. The nature of their disability subjects them to the constant threat of deterioration-psychological, social and medical. Thus, the true results of spinal cord injury services cannot be adequately evaluated without follow-up data accumulated during successive post-injury years. We may find we are doing some unessential or detrimental things and omitting some critical things in the rehabilitation process.

Spinal cord injury is a low incidence disability (35 per million population in the United States) with almost infinite variables-medical, psychological and social - compounded by time. It is little wonder that no one professional discipline, one hospital, one rehabilitation center or one agency has ever produced adequate data to provide a composite view of the consequences of spinal cord injury. In order to permit sophisticated manipulation of data with resultant statistically significant information the data bank must contain approximately three to four thousand well-documented cases.

The National Spinal Cord Injury Data Research Center has been established at Good Samaritan Hospital, Phoenix, Arizona, by the Rehabilitation Services Administration, Department of Health, Education and Welfare, to meet the need for a centralised data collection and information source. The project has been 
PAPERS READ AT THE ANNUAL SCIENTIFIC MEETING, I 975

funded for a period of two years, commencing on I September 1975. During that period a mechanism will be developed to extend the operations for at least a decade.

\section{Methodology}

The primary research tool of the project will be the Common Data Base which has been in the process of refinement over the past five years. The Common Data Base represents the conjoint effort of many individuals from multi-professional disciplines representing all of the Health, Education and Welfare sponsored Spinal Cord Injury Research and Demonstration Projects. It includes a distillate of the variables surviving the original data base established by the Southwest Regional System for Treatment of Spinal Injury. It also includes variables added by other Centers during the course of several conferences held to work on a Common Data Base. The Department of Health, Education and Welfare Regional Spinal Cord Injury System sent representatives to conferences held in Houston in 1972; Chicago in 1973; Washington, D.C. in 1974; and Virginia in 1975, for the specific purpose of developing a Common Data Base. The American Spinal Injury Association, whose membership represents a number of Spinal Cord Injury Centers in the U.S.A. including the Regional Demonstration Centers, has devoted two sessions to developing a Common Data Base. The International Medical Society of Paraplegia representing Spinal Cord Centres throughout the world has a committee working on a Common Data Base. The data base to be used by the proposed project has been carefully developed from all these resources.

The variables within the data base have been selected on the basis of collectability, reliability, retrievability and meaningfulness with respect to developing the critical information required by the project. The data base will reflect the pre-injury status, the events of the injury, the events of the initial treatment and rehabilitation, and the events occurring during successive years following the injury. (Copies of the Common Data Base, its report form and syllabuses are available on request to the author.)

The working plan will require each cooperating Reporting Center to collect and record, using the prescribed format, the basic data which will then be sent to the National Data Bank in hard copy form. Once received at the National Spinal Cord Injury Data Research Center, the data will be identified and entered into the data bank where individual data processing steps, including classification, sorting, calculation, storage, retrieval and summarisation will be facilitated through computerisation. Security control will preclude unauthorised use of the consolidated spinal cord injury data.

In keeping with the stated purposes of the project, the data collection protocols and subsequent data analysis will be geared primarily to provide useful multidisciplinary epidemiological information. Descriptive and inferential statistical analysis of the bi-variate and multi-variate type will be employed on the combined data to help answer the variety of relevant research questions which have been posed. Examples of questions to be addressed specifically are: (I) economic and humanitarian costs of spinal cord injury; (2) significant variables involved in preventative maintenance services; (3) the efficiency of the system management approach to treatment. Also, analysis of these combined data can further document the productivity of a system approach as compared to the unsystematic approach of providing care for the spinal cord injured. Perhaps most importantly, the accumulated data base, once appropriately collected and stored, will provide a 
valuable foundation for a variety of future research studies aimed at upgrading the quality of spinal cord injury care available to the public.

The information generated by the project will be distributed by means of periodic written reports and publications and audiovisual media to all of those having interest and responsibility in developing and paying for optimal spinal cord injury services in the United States.

Collecting of data from the ten Health, Education and Welfare supported spinal cord injury centers began in September of 1975. It is estimated that data on two thousand cases will be collected during a two-year period from these Centres.

There are a number of established rehabilitation centres in the United States providing services for spinal cord injured patients. Selected centres will be invited to contribute data to the National Spinal Cord Injury Data Research Center. Approximately five hundred cases should be generated from this group. In the United States General Hospitals provide most of the medical and surgical services for spinal cord injured patients. There are many that have Departments of Physical Medicine and Rehabilitation. Commonly, they provide all of the acute medical and rehabilitation services required by the spinal cord injured. Selected General Hospitals with Departments of Physical Medicine and Rehabilitation will be invited to participate in the National Spinal Cord Injury Research Center Project. Approximately, five hundred cases should be generated from this group.

Collection of the data will require some organisational effort on the part of the centers and hospitals. Completion of the forms will require some time and expense. However, both chores should not unduly tax the operating budget of the voluntarily contributing facilities.

The insurance industry in the United States has in its files cases of spinal cord injury covered by Workmen's Compensation. This group has a unique quality. They are well documented, particularly in regards to the medical care provided. Most important, they document the cost of all services provided. Nowhere else in the United States is this information available with any reliability. Even though the cases represent a select population, the completeness of the documentation makes them an invaluable source of information. When combined with an adequate data bank, the cost experience of the insurance industry can be manipulated and interpolated to cover a more typical population. Furthermore, the insurance industry, of necessity, has had to purchase the services provided in the market place. As a consequence, these cases will serve as controls for the Regional Spinal Cord Injury Demonstration Systems. It is hoped that a reporting mechanism can be established to enable data from at least five hundred workmen compensation cases to flow into the National Data Bank.

The largest control group of spinal cord injured patients in the United States is served by the Veterans' Administration. The Spinal Cord Injury Service of the Veterans' Administration has been invited to participate in the National Spinal Cord Injury Data Research Center Project. When achieved, this group of cases will serve as an additional control group representing a different form of system management.

\section{SUMMARY}

The National Spinal Cord Injury Data Research Center has been established at Good Samaritan Hospital, Phoenix, Arizona by the Department of Health, 
Education and Welfare to develop information related to spinal cord injury in the United States. The research questions to be addressed by the project have been designed to define the magnitude and composition of the spinal cord injured population. How well does the spinal cord injured person cope with his disability? How much and what kind of services does he consume? How much does it cost? What does he produce? The project should add to our knowledge of the optimal methodology for delivery of proper services at the proper time at minimal cost to reduce the disability created by this catastrophic injury.

Following the presentation of the above paper, I6 international spinal cord injury centers expressed their desire to participate in the United States Data Center Project.

\section{RÉSUMÉ}

Le Centre national des recherches pour l'information concernant les blesures à la moelle épinière a été établi à l'hôpital Good Samaritan à Phoenix en Arizona par H. E. W. (le Ministère de la Santé, de l'Education et de l'Aide Sociale) pour développer des informations afférentes à la blessure à la moelle épinière aux Etats-Unis. Les questions de recherche dont le projet s'occupera ont été préparées pour définir la grandeur et la composition de la population des blessés à la moelle épinière aux Etats-Unis. A quel degré le blessé à la moelle épinière s'accomode-t-il à son infirmité? Combien et de quelle espèce de service en est-il question? Quels en sont les frais? Quelle est la productivité d'un tel blessé? Le projet doit ajouter à notre connaissance de la méthodologie optimale pour la livraison des services corrects en temps opportun aux frais minimaux pour réduire l'infirmité créée par cette blessure catastrophique.

Suivant la présentation du mémoire ci-dessus, seize centres internationaux des blessures à la moelle épinière ont exprimé leur désir de s'associer au Projet du Centre des informations aux Etats-Unis.

\section{ZUSAMMENFASSUNG}

Das National Spinal Cord Injury Data Research Center wurde im Good Samaritan Hospital, Phoenix durch das Department of Health, Education und Welfare eingerichtet, um Information über Rückenmarkverletzungen zu entwickeln. Die Forschungs-Fragen betreffen die Bedeutung und Komposition der querschnittsgelähmten Bevölkerung in USA. Wie gut wird der Querschnittsgelähmte mit seiner Disabilität fertig? Wie viele und welche Art von Dienstleistungen brancht er? Wie hoch sind die Kosten? Was produziert er? Das Projekt wird unsere Kenntnis einer optimalen Methodologie bereichern, um gelignete Dienleistungen zeitgemäss und mit minimalen Kosten zu ermöglichen, um die durch die Katastrophe bedingte Disabilität zu verringern.

Seit der Veröffentlichung dieser Publikation haben I6 internationale spinale Zentren ihre Bereitwilligkeit gezeigt, an dem United States Data Zentrum mitzwarbeiten.

\section{REFERENCES}

AfFeldt, J. E. (1958). Functional and vocational recovery in severe poliomyelitis. Clin. Orthop., 12, I6-21.

Bors, E. (I956). The challenge of quadriplegia: some personal observations in a series of 233 cases. Bulletin of the Los Angeles Neurological Society, 21, I05-I23.

GuttmanN, L. (1973). Spinal Cord Injuries: Comprehensive Management and Research. Oxford, England: Blackwell Scientific Publications. $687 \mathrm{pp}$.

LANDAUER, K. S. (I957). A national program of respiratory and rehabilitation centers. Proceedings of the Fourth International Poliomyelitis Congress, Geneva, Switzerland, July 8-I2.

LANDAUER, K. S. \& Stickle, G. (I958). An analysis of residual disabilities (paralysis and crippling) among I00,000 poliomyelitis patients: with special reference to the rehabilitation of postpoliomyelitis patients. Arch. Phys. Med. Rehabil. 39, no. 3, I45-I5I.

$I 4 / I-G$ 
MUNRo, D. (1948). The care of patients paralyzed as the result of injury to the spinal cord and cauda equina. Med. Clin. N. Amer. 32, 1273-I291.

SPENCER, W. A. (1958). Comments on interdisciplinary contributions in the care of the neuromuscularly disabled. Ann. N.Y. Acad. Sc. 74, no. I, I IO-I I6.

StAUfFer, E. S., Wilcox, N. E., Nickel, V. L. \& ERICKsON, E. R. (1969). Interdisciplinary Clinical, Educational and Research Aspects of a Regional Center for the Rehabilitation of Spinal Cord Injured Persons. A final report of S.R.S. Grant RD2II4M-68-C2. Rancho Los Amigos Hospital, Downey, California.

YounG, J. S. (1970). Development of systems of spinal cord injury management with a correlation to the development of other esoteric health care systems. Arizona Medicine, 27, no. 8, I-6. 